\title{
STUDI POTENSI EKOWISATA DANAU PULAU SATONDA DI DESA NAGAMIRO KECAMATAN PEKAT KABUPATEN DOMPU PROVINSI NUSA TENGGARA BARAT
}

\author{
Rugayah', Galit Gatut Prakosa $^{1}$, Nugroho Tri Waskitho', Febri Arif Cahyo W' \\ 'Jurusan Kehutanan Fakultas Pertanian-Peternakan Universitas Muhammadiyah Malang \\ Email: galitgatut@gmail.com
}

\section{RANGKUMAN}

Danau Pulau Satonda merupakan objek wisata yang diminati banyak wisatawan baik wisatawan lokal maupun wisatawan mancanegara, serta memiliki potensi keanekaragaman hayati berupa flora dan fauna yang cukup melimpah. Namun, pengelolaan kawasan tersebut belum dilakukan secara optimal, baik ditinjau dari sarana dan prasarana maupun keterlibatan dinasdan masyarakat setempat dalam pengelolaannya. Tujuan dari penelitian ini adalah mengetahui strategi pengembangan ekowisata di Danau Pulau Satonda. Data melalui observasi lapangan, dokumentasi, kuesioner, dan wawancara untuk memperoleh data terkait potensi ODTWA (Objek Daya Tarik Wisata Alam), sarana dan prasarana objek wisata, serta persepsi masyarakat dan minat pengunjung. Data dianalisis melalui analisis SWOT untuk menentukan strategi pengembangan ekowisata di Danau Pulau Satonda. Hasil analisis SWOT menunjukkan bahwa pengembangan ekowisata Danau Pulau Satonda diprioritaskan menggunakan strategi berdasarkan SO (strength and opportunities) dengan pertimbangan bahwa sumberdaya ekowisata mempunyai potensi yang cukup besar, akan tetapi belum dimanfaatkan secara optimal.

Kata Kunci: Ekowisata, Danau Pulau Satonda, Strategi Pengembangan

\begin{abstract}
Satonda Island Lake is a tourist attraction that attracts many tourists, both local and foreign tourists, and has abundant biodiversity in the form of flora and fauna. However, the management of the area has not been carried out optimally, both in terms of facilities and infrastructure and the involvement of the local government and community in its management. The purpose of this study was to find out the strategy for developing ecotourism on Satonda Island Lake. Data through field observations, documentation, questionnaires, and interviews to obtain data related to the potential of ODTWA (Nature Tourism Attraction Objects), tourist facilities and infrastructure, as well as public perceptions and interests of visitors. Data were analyzed through SWOT analysis to determine the strategy for developing ecotourism on Satonda Island Lake. The results of the SWOT analysis show that the development of Satonda Island Lake ecotourism is prioritized using SO (strength and opportunities) strategies with the consideration that ecotourism resources have considerable potential, but have not been utilized optimally.
\end{abstract}

Keywords: Ecotourism, Satonda Island Lake, Development Strategy 


\section{Pendahuluan}

Indonesia memiliki potensi yang sangat besar dalam pengembangan ekowisatakawasan hutan tropika. Kawasan hutan yang dapat berfungsi sebagai kawasanwisata berbasis lingkungan adalah Kawasan Pelestarian Alam (taman nasional,taman hutan raya, taman wisata alam), Kawasan Suaka Alam (suaka margasatwa dan cagar alam), hutan lindung melalui kegiatan wisata alam terbatas, serta hutan produksi yangberfungsi sebagai wana wisata. Kawasan - kawasan tersebut merupakan destinasi yang diminati oleh wisatawan, karena memiliki keanekaragaman flora dan fauna, fenomena alam yang indah,objek budaya dan sejarah, serta kehidupan masyarakat lokal yang unik. Keseluruhanobjek daya tarik wisata ini merupakan sumberdaya yang memiliki nilai ekonomi tinggi sekaligus sebagai sarana pendidikan dan pelestarian lingkungan (Fandelli, 2005). Potensi pariwisata di sekitar kawasan yang dilindungi merupakan salah satucara terbaik untuk mendatangkan keuntungan ekonomi kawasan terpencil, dengan cara menyediakan kesempatan kerja masyarakat setempat, merancang pasar, serta memperbaiki saranadan komunikasi (Mackinnon et al, 1990).

Hal yang penting dan perlu diperhatikan dalam ekowisata di Indonesia adalah keikutsertaan masyarakat setempat dalam setiap kegiatan kepariwisataan (Usman, 1999). Ekowisata berbasis masyarakat artinya masyarakat lokal yang mempunyai kendali penuh dan terlibat di dalamnya baik itu di manajemen dan pengembangannya, sertaproporsi yang utama menyangkut manfaat di dalam masyarakat. Adanya potensi wisata di suatu tempat akan memberikan berbagai keuntungan baik bagi masyarakat dan lingkungan sekitarnya. Mackinnon et al (1990) menyatakan bahwa potensi pariwisata disekitar kawasan yang dilindungi merupakan salah satucara terbaik untuk mendatangkan keuntungan ekonomi kawasan terpencil, dengan cara menyediakan kesempatan kerja masyarakat setempat, merancang pasar setempat, serta memperbaiki saranadan komunikasi. Penawaran pariwisata yang berupa produk kepariwisataan terdiri atas tiga komponen yaitu atraksi wisata, jasa wisata dan angkutan wisata (Soekadijo, 2000). Produk kepariwisataan akandiperoleh melalui pelaksanaan ekowisata yang melibatkan masyarakat mulai dari tahap perencanaan, pengelolaan, dan pemantauan karena masyarakat lokal, terutama penduduk asli yang bermukim di kawasan wisata, menjadi salah satu pemain kunci dalam pariwisata. Melalui pelibatan masyarakat dalam kegiatan wisata alam, diharapkan mampu mengupayakan keuntungan finansial sekaligus sebagai alternatif peningkatan taraf hidup masyarakat.

Salah satu kawasan konservasi yang memiliki potensi ekowisata yaitu Danau Pulau Satonda yang terletak di Kabupaten Dompu, Nusa Tenggara Barat. Kawasan konservasi seluas $2600 \mathrm{Ha}$ ini ditunjuk sebagai Taman Wisata Alam (TWA) oleh Kementerian Kehutanan berdasarkan Surat Keputusan Menteri Kehutanan Nomor 22/Kpts-VI/1998 tanggal 7 Januari 1998. Danau ini mempunyai keunikan karena airnya asin seperti air laut 
dengan salinitas sekitar 29,4-37,2\%. Diperkirakan air danau ini asin karena tercampur dengan air laut yang meluap dan terperangkap di danau pada saat Gunung Tambora meletus.Jarak danau dengan Gunung Tambora berdekatan dan seperti diketahui letusan Gunung Tambora merupakan letusan yang sangat dahsyat sehingga sangat mungkin menimbulkan gelombang pasang (tsunami). Danau Pulau Satonda merupakan salah satu objek wisata yang banyak diminati wisatawan, baik dalam negeri maupun mancanegara. Namun, pengelolaan kawasan Danau Pulau Satonda ini dirasa belum dilakukan secara optimal, baik ditinjau dari sarana dan prasarana maupun keterlibatan dinas dan masyarakat setempat dalam pengelolaannya. Kebijakan Pemerintah Daerah Nusa Tenggara Baratdalam kaitannya dengan kebijakan perlindungan kawasan hutan dan pengelolaan kawasan ekowisata termasuk taman nasional hingga saat ini belum memiliki produk hukum (Riyanto, 2005). Oleh karena itu, perlu dilakukan penelitian untuk mengkaji strategi pengembangan ekowisata di Danau Pulau Satonda.

\section{Metode Penelitian}

\section{Lokasi dan Waktu Penelitian}

Penelitian ini dilaksanakan pada bulan Februari 2017 di TWA Danau Pulau Satonda. Kawasan ini terdiri dari daratan $(453,70 \mathrm{Ha})$ dan luas perairan (2146,3 Ha). Berdasarkan letak astronominya, TWA Danau Pulau Satonda berada pada $8^{\circ} 05^{\prime} 53^{\prime \prime}-8^{\circ} 07^{\prime} 15^{\prime \prime}$ LS dan 117\%43'59'-117\%45'27'BT. Secara administratif, berada diwilayah Desa Nangamiro, Kecamatan Pekat, Kabupaten Dompu, Propinsi Nusa Tenggara Barat. Peta lokasi disajikan pada Gambar 1

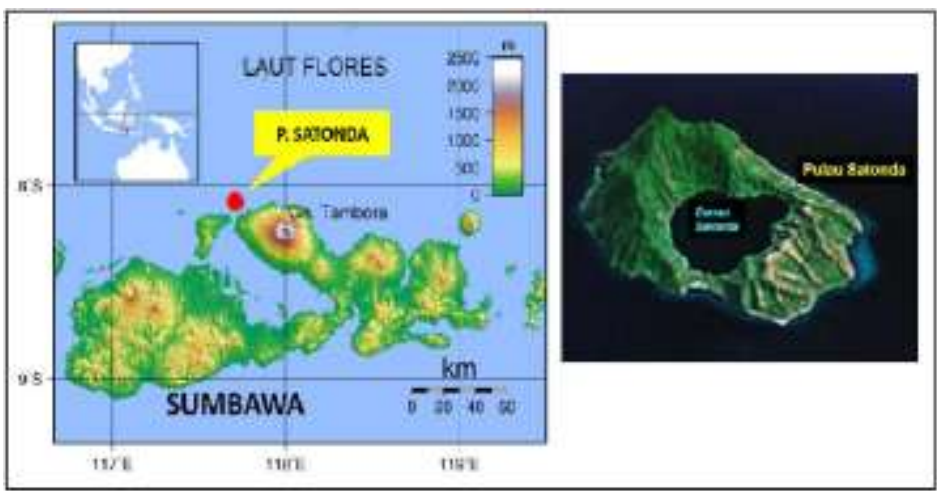

Gambar 1. Peta Lokasi Penelitian

\section{Metode Pengumpulan Data}

Data yang dibutuhkan dalam penelitian ini berupa data primer dan data sekunder. Data primer yang dibutuhkan berupa 1) potensi ODTWA (Objek Daya Tarik Wisata Alam) antara lain kondisi flora dan fauna, gejala alam, keindahan alam, panorama, ketersediaan air bersih, hubungan dengan objek wisata sekitar, keamanan, objek wisata alam, dan akomodasi; 2) sarana dan prasarana objek wisata; dan 3) persepsi masyarakat dan motivasi pengunjung. Data tersebut diperoleh 
melalui observasi lapangan (field survey), dokumentasi, kuesioner, dan wawancara. Sedangkan data sekunder yang dibutuhkan berupa data penduduk dan kondisi geografis. Data sekunder diperoleh dari Balai Taman Wisata Alam Danau Pulau Satonda dan instansi terkait lainnya.

\section{Analisis Data}

Data dianalisis dengan menggunakan analisis SWOT (Strengths, Opportunities, Weakness, Threats) untuk menentukan strategi pengembangan ekowisata Danau Pulau Satonda berdasarkan faktor kekuatan, peluang, kelemahan, dan ancaman. Analisis SWOT dibatasi pada kajian sektoral dimana ekowisata ditetapkan sebagai lingkungan internal, sedangkan lingkungan eksternal mencakup keseluruhan lingkungan di luar sektor ekowisata. Faktor internal yang menjadi kekuatan dan kelemahan serta faktor eksternal yang menjadi peluang dan ancaman dilakukan identifikasi dan evaluasi.

Faktor internal yang diindentikasi dan dievaluasi meliputi aspek, yaitu: (a) sumberdaya ekowisata dan (b) kelembagaan; sedangkan faktor eksternal meliputi bidang (a) sosial dan budaya, (b) ekonomi dan politik, (c) lingkungan global, dan (d) teknologi. Faktorfaktor internal dan eksternal yang telah diidentifikasi, kemudian diberikan bobotdan peringkat untuk menentukan faktor yang paling dominan dalam masing-masing kolom kekuatan, kelemahan, peluang, dan ancaman. Faktor-faktor yang paling dominan kemudian dimasukan dalam Matriks SWOT. Menurut Rangkuti (2006), hasil analisa SWOT tersebut dapat menghasilkan 4 (empat) kemungkinan strategi alternatif,yaitu:

- Strategi (SO), dibuat berdasarkan kekuatan untuk merebut dan memanfaatkan peluang sebesar-besarnya.

- Strategi (WO), strategi ini diterapkan berdasarkan pemanfaatan peluang yang ada dengan cara meminimalkan kelemahan yang ada.

- Strategi (ST), strategi dalam menggunakan kekuatan yang dimiliki untuk mengatasi ancaman.

- Strategi (WT), strategi ini didasarkan pada kegiatan yang bersifat defensif dan berusaha meminimalkan kelemahan yang ada serta menghindari ancaman.

\section{Hasil dan Diskusi}

Gambaran Umum Danau Pulau Satonda

Danau Pulau Satonda terletak disuatu pulau kecil yang bernama Pulau Satonda, terletak dilaut Flores, sebelah utara Pulau Sumbawa, Kabupaten Dompu, Propinsi Nusa Tenggara Barat. Nama asli danau ini adalah Danau Motitoi, tetapi lebih populer dikenal dengan nama Danau Satonda. Danau ini tersohor didunia ilmu pengetahuan sejak tahun 1984. Pertama kali ditemukan sebagai danau yang mempunyai ciri yang sangat unik, mirip dengan kondisi samudra zaman purba. Danau Pulau Satonda dipandang sebagai jendela kontemporer untuk dapat melihat kondisi laut miliaran tahun lampau. Danau Pulau Satonda telah menjadi salah satu "palaeo- oceano graphic laboratory" atau "laboratorium oseano grafi purba" yang paling menarik dan unik di dunia. 
Danau Pulau Satonda mempunyai dua kawah (crater) bersusun. Dinding kawah danau berdiri tegak setinggi $300 \mathrm{~m}$ diatas permukaan laut. Depressi atau bagian cekungan yang membentuk danau terjadi karena runtuhnya kantong magma vulkanik sekitar 10.000 tahun lalu hingga membentuk satu kaldera. Keunikan Danau Pulau Satonda dalam ilmu pengetahuan bermula ketika diadakan eskpedisi oseano grafi Snellius II dengan kapalriset Tyro ditahun 1984,yang merupakan kerjasama Indonesia-Belanda. Hasil pengukuran berbagai parameter kimia ditemukan berbagai formasi karbonat serta berbagai bentuk kehidupan didanau dengan fosildiera palaeozoic (miliaran tahun lalu). Temuan dilanjutkan dengan ekspedisi kapal riset Sonneke Danau Pulau Satonda yang merupakan ekspedisi oseanografi IndonesiaJerman di tahun 1986. Dua ilmuwan Eropa yang berperan menyingkap rahasia Danau Pulau Satonda adalah Kempe dan Kazmierczak. Menurut pendapat Kempe dan Kazmierczak, Danau Pulau Satonda merupakan fenomena langka karena air asin dengan alkalinitas (tingkat kebasaan) disertai $\mathrm{pH}$ dan kelarutan karbonat yang sangat tinggi dibandingkan dengan air laut umumnya. Kondisi lingkungan umumnya akan menumpas kehidupan biota makro (macrobiota) dan kenyataannya tidak ada kehidupan biota makro yang bisa dijumpai di Danau Pulau Satonda. Danau ini sebaliknya dijumpai struktur berkapur seperti terumbu (calcareousreeflikestructures) yang terdiri dari algamerah, serpulid (cacing tabung),dan foraminifera, serta cyanobacteria yang mengendapkan kapur dan membentuk formasi karbonat yang disebut stromatolit. Struktur stromatolit mirip dengan tipe stromatolit yang tersebar luas disamudera pada era awal plaeozoicum sekitar 4.500 juta tahun lalu. Menurut Kempe dan Kazmierczak, hujan membuat permukaan air danau menjadi lebih tawar. Salinitas permukaan danau berkurang akibat letusan dahsyat Gunung Tambora tahun 1815, yang letaknya hanya sekitar $30 \mathrm{~km}$ di sebelah timur Satonda. Letusan Gunung Tambora, yang merupakan letusan terdahsyat yang pernah tercatat dalam sejarah, telah menghancurkan hutan di Danau Pulau Satonda. Pepohonan menyebabkan berkurangnya penguapan dan air hujan banyak yang terkumpul di kawah, sehingga menyebabkan lapisan air bagian atas menjadi lebih tawar. Pada saat yang sama, sebagian air yang lebih tua dan lebih asin tertekan ke bawah atau keluar danau melalui pori-pori bebatuan vulkanik yang terbuka.

Karakteristik dan kondisi alam Danau Pulau Satonda inilah yang menarik untuk pengembangan pariwisata dan telah dinobatkan sebagai Taman Wisata Alam Danau Pulau Satonda pada tahun 1999 lewat Keputusan Menteri Kehutanan dan Perkebunan. Taman Wisata dikelola oleh Balai Konservasi Sumber Daya Alam Nusa Tenggara Barat. Taman Wisata Alam menawarkan adanya danau yang unik seperti lingkungan pulau, pantai berpasir dan laut dengan terumbu karang yang kaya mengelilingi Danau Pulau Satonda. Keunikan alam dan potensi sumberdaya ekowisata di Danau Pulau Satondatelah menarik banyak wisatawan mancanegara maupun lokal. 
Temuan ilmiah yang mengindikasikan Danau Pulau Satonda sebagai laboratorium oseanografi purba.Danau Pulau Satonda menawarkan kondisi alam yang sangat menarik untuk pengembangan pariwisata dan telah dinobatkan sebagai Taman Wisata Alam DanauPulau Satonda. Kawasan ini dikelola oleh Balai Konservasi Sumber Daya Alam Nusa Tenggara Barat. Taman Wisata Alam menawarkan adanya danau yang unik seperti lingkungan pulau, pantai berpasir dan laut dengan terumbu karang yang kaya mengelilingi Danau Pulau Satonda. Keunikan alam di Danau Pulau Satonda telah menarik banyak turis lokal maupunmancanegara. Terdapat berbagai potensi sumberdaya ekowisata di Danau Pulau Satonda antara lain potensi flora dan fauna, objek wisata, serta sarana dan prasarana.

\section{1) Jenis flora dan fauna}

Secara umum jenis flora dan fauna yang ada diDanau Pulau Satonda antara lain Ketapang (Terminalia catappa), Pandan Laut (Pandanustectorius), Beringin (Ficus sp), Waru Laut (Hibiscus tiliaceus), Nyamplung (Calophyllum inophyllum), Mentigi (Pemphis acidula) dan Asam (Tamarindus indica). Jenis fauna antara lain Rusa (Cervus timorensis), Babi Hutan (Sus scrova),Monyet Ekor Panjang (Macaca fascicularis), Porcupine(Hystrix javanica), Kelalawar (Pteropus vampir)Ayam Hutan,Pergam Hijau, Kepodang, Tekukur, dan Burung Puyuh.

2) Objek wisata

Objek wisata di Danau Pulau Satonda berupa pasir putih pantai dan pemandangan dari atas bukit, serta terumbu karang. Beberapa kegiatan wisata yang dapat dilakukan di kawasan wisata tersebut adalah snorkeling dan scuba diving dengan pemandangan berupa terumbu karang.

3) Sarana dan prasarana

Taman wisata alam Danau Pulau Satonda menyediakan beberapa sarana dan prasarana seperti kursi payung, restoran, tangga menuju Danau Pulau Satonda, serta dermaga untuk persinggahan perahu atau boat sebagai fasilitas penunjang wisatawan. Fasilitas lain yang terdapat di Danau Pulau Satonda antara lain penginapan (homestay) dan warung kecil sebagai penunjang perekonomian masyarakat sekitar.

4) Aksesibilitas

Perjalanan ke Satonda atau Pulau Satonda yang terletak di Laut Flores ini, sekitar tiga kilometer dari Semenenanjung Sanggar. Kordinat posisinya, $8^{\circ} 7^{\prime}$ Lintang Selatan dan $117^{\circ} 45^{\prime}$ Bujur Timur.

Pengunjung setiap tahun didominasi oleh pengunjung asing yang datang dari Paris, Canada, Swiss dan Singapura.Sedangkan untuk pengunjung lokal didominasi dari Jawa Barat, Jawa Timur, Jakarta, Bandung, Bogor, Bima, Dompu, dan Sumbawa.Budaya yang masih dikembangkan sebagai potensi yang menarik perhatian pengunjung antara lain yaitu tarian musik sasando, tarian buja kadanda (tarian bersenjatakan tombak dan perisai) yang merupakan tarian yang menggambarkan dua prajurit yang sedang berperang, tarian lenggo, dan tarian wura bongi monca. Sebagian besar pengunjung atau wisatawan yang berwisata ke Danau Pulau Satonda memiliki motivasi untuk 
melalukan kegiatan snorkeling ataupun diving dengan objek yang paling menarik perhatian yaitu danau air asin dan pemandangan terumbu karang bawah laut.

Karakteristik masyarakat di kawasan Danau Pulau Satonda dapat dilihat dari jenis pekerjaan yang didominasi oleh petani dan wiraswasta serta tingkat pendidikan yang didominasi lulusan sekolah menengah atas. Hasil wawancara menunjukkan bahwa sebelum berkembangnya kegiatan wisata di Danau Pulau Satonda, kehidupan mereka hanya bergantung dari sumber daya alam khususnya laut. Kegiatan wisata di Danau Pulau Satonda saat ini telahmeningkatkan taraf perekonomian masyarakat sekitar. Mereka sangat mendukung kawasan tersebut sebagai kawasan konservasi dimana masyarakat dapat ikut serta mengelolanya sebagai tempat wisata. Peluang usaha serta kerja yang dapat dilakukan masyarakat dalam rangka pengembangan ekowisata di Danau Pulau Satonda yaitu jasa transportasi, penginapan (homestay), serta restoran atau cafe. Kendala yang dialami masyarakat adalah kemampuan berbahasa inggris, sedangkan pengunjung atau wisatawasan di kawasan tersebut didominasi wisatawan mancanegara.

\section{Strategi Pengembangan Ekowisata}

Strategi pengembangan ekowisata pada Kawasan Danau Pulau Satonda dirumuskan melalui analisis SWOT yang meliputi analisis lingkungan internal dan analisis lingkungan eksternal. Terdapat 4 aspek yang harus diperhatikan yaitu kekuatan (strength/S), kelemahan (weakness/W), peluang (opportunity/O), dan ancaman (threat/T). Berikut disajikan faktor - faktor baik internal maupun eksternal yang mempengaruhi pengembangan ekowisata Danau Pulau Satonda, pada Tabel 1 dan Tabel 2.

Tabel 1. Faktor - Faktor Internal dan Eksternal dalam Pengembangan Ekowisata Danau Pulau Satonda No Uraian

$1 \quad$ Faktor Lingkungan Internal

a. Kekuatan

1. Keanekaragaman tipe ekosistem beserta sumber daya alam di dalamnya berupa flora, fauna, lanskap, dan keanekaragaman budaya di TWADanau Pulau Satonda sangat berpotensi sebagai objek daya tarik wisata.

2. Telah teridentifikasinya objek dan daya tarik wisata, baik atraksi alam maupun atraksi budaya.

3. Tersedianya fasilitas yang memadai guna mendukung pengembangan wisata.

4. Dukungan dan respon positif masyarakat setempat untuk ikut berpartisipasi secara aktif dalam pengelolaan dan pengembangan ekowisata di TWA Danau Pulau Satonda.

5. Pariwisata dijadikan sebagai aktivitas ekonomi penduduk disamping usaha perikanan dan nelayan.

6. Penduduk setempat menguasai informasi atrakasi wisata yang cukup baik untuk pengembangan wisata ke depan. 


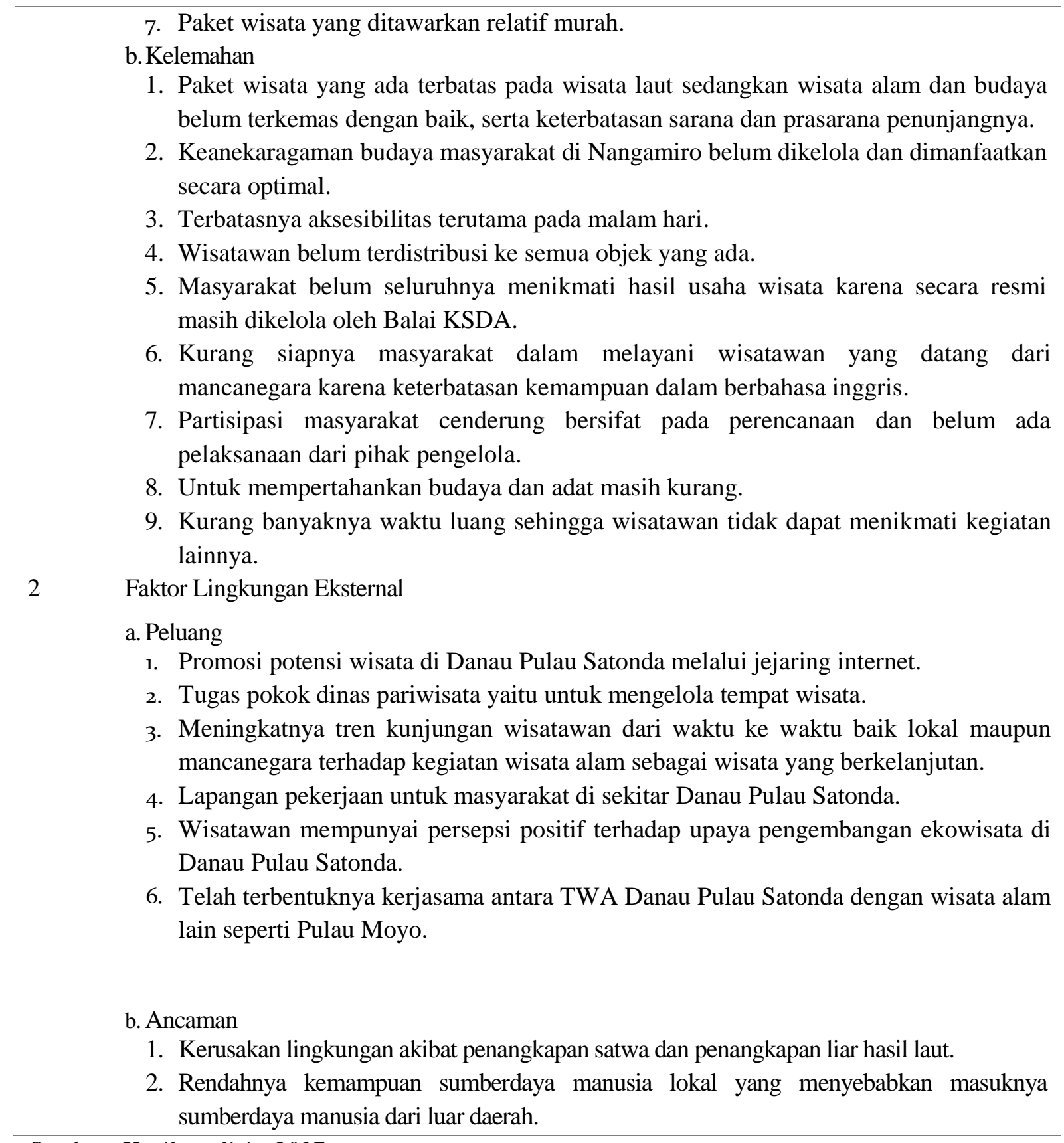

Sumber: Hasil analisis, 2017

Berdasarkan 4 aspek yaitu kekuatan, kelemahan, peluang, dan ancaman, maka dirumuskan strategi yang dapat dilakukan guna pengembangan ekowisata Danau Pulau Satonda sebagai berikut:

1. Strategi berdasarkan kekuatan-peluang (S-O) Mengembangkan seluruh potensi yang ada baik itu potensi sumberdaya alam seperti keanekaragaman hayati (flora dan fauna), keindahan bentang alam, dan potensi yang belum bisa dikembangkan berupa kebudayaan lokal masyarakat yang dapat dikemas dalam satu paket wisata dengan memanfaatkan dukungan dari pemerintah daerah setempat dan dukungan masyarakat lokal.

2. Strategi berdasarkan kelemahan-peluang (WO) 
Menarik serta memanfaatkan dukungan dari pemerintah daerah dan masyarakat untuk lebih mengoptimalkan peningkatan kualitas obyek wisata Danau Pulau Satonda baik fasilitas, pelayanan publik, sarana dan prasarana, serta menggalakkan gerakan sadar wisata dan kegiatan promosi wisata budaya yang menarik minat wisatawan mancanegara dan wisatawan lokal seperti kegiatan tracking, outbound, pengamatan satwa, agrowisata, wisata kuliner, lomba foto satwa, dan lain-lain.

3. Strategi berdasarkan kekuatan-ancaman (S-T) Mengoptimalkan pengawasan di seluruh elemen dan sektor di lapangan,melakukan pembinaan habitat dan populasi terhadap jenis fauna yang semakin punah, meningkatkan kesadaran dan pembinaan terhadap masyarakat setempat dengan memberikan penyuluhan - penyuluhan tentang manfaat obyek wisata bagi mereka serta mengajak masyarakat untuk berpartisipasi aktif dalam menjaga kelestarian hutan dan obyek wisata yang ada di untuk meningkatkan taraf hidup bagi masyarakat itu sendiri.

4. Strategi berdasarkan kelemahan-ancaman (W-T)

Menggalakan komunikasi intensif dan sinergitas dengan stakeholder yang berkompeten antara lain yaitu dinas pariwisata, unit KSDA, pihak UPTD pengelola kawasan,akademisi, LSM, organisasi masyarakat yang berbasis pada pengembangan kebudayaan maupun pengembangan wisata serta masyarakatuntuk ikut terlibat dalam lintas kerjasama maupun bekerjasama dalam bentuk kegiatan pengembangan Kawasan wisata mulai dari perencanaan, sampai pada tahap pengelolaan Kawasan wisata yang ada

Tabel 2. Internal Factor Analysis Summary (IFAS)

No Faktor Strategi Internal $\quad$ Bobot Rating Skor Kode

\section{A Kekuatan (S)}

1 Keanekaragaman tipe ekosistem beserta sumber daya alam $\begin{array}{llll}0,05 & 4 & 0,8 & \mathrm{~S} 1\end{array}$ di dalamnya berupa flora, fauna, lanskap, dan keanekaragaman budaya di TWA Danau Pulau Satonda sangat berpotensi sebagai objek daya tarik wisata.

2 Telah teridentifikasinya objek dan daya tarik wisata baik atraksi alam maupun atraksi budaya.

3 Tersedianya fasilitas yang memadai guna mendukung $0,05 \quad 3 \quad \begin{array}{llll}0,15 & \text { S3 }\end{array}$ pengembangan wisata.

4 Dukungan dan respon positif masyarakat setempat untuk

$\begin{array}{llll}0,1 & 4 & 0,4 & \mathrm{~S} 4\end{array}$
ikut berpartisipasi secara aktif dalam pengelolaan dan pengembangan ekowisata.

5 Pariwisata dijadikan sebagai aktivitas ekonomi penduduk disamping usaha perikanan dan nelayan

6 Penduduk setempat menguasai informasi atrakasi wisata yang cukup baik untuk pengembangan wisata ke depan.

$\begin{array}{llll}0,05 & 4 & 0,2 & \mathrm{~S} 5\end{array}$

$0,05 \quad 3 \quad 0,15 \quad$ S6




\section{B $\quad \operatorname{Kelemahan}(\mathbf{w})$}

1 Paket wisata yang ada terbatas pada wisata laut sedangkan wisata alam dan budaya belum terkemas dengan baik serta keterbatasan sarana dan prasarana penunjangnya.

2 Keanekaragaman budaya masyarakat di Nangamiro belum dikelola dan dimanfaatkan secara optimal.

3 Terbatasnya aksesibilitas terutama pada malam hari.

4 Wisatawan belum terdistribusi ke semua objek yang ada.

5 Masyarakat belum seluruhnya menikmati hasil usaha wisata karena secara resmi masih dikelola oleh Balai KSDA.

6 Kurang siapnya masyarakat dalam melayani wisatawan yang datang dari mancanegara karena keterbatasan kemampuan dalam berbahasa inggris.

7 Partisipasi masyarakat cenderung bersifat pada perencanaan dan belum ada pelaksanaan dari pihak pengelola.

8 Untuk mempertahankan budaya dan adat masih kurang .

9 Kurang banyaknya waktu luang sehingga wisatawan tidak dapat menikmati kegiatan lainnya. Jumlah

$\begin{array}{llll}0,05 & 3 & 0,15 & \mathrm{~W} 1\end{array}$

$\begin{array}{llll}0,05 & 3 & 0,15 & \text { W2 }\end{array}$

$\begin{array}{llll}0,04 & 2 & 0,1 & \mathrm{~W} 3\end{array}$

$\begin{array}{llll}0,03 & 2 & 0,06 & \mathrm{~W} 4\end{array}$

$0,06 \quad 1 \quad 0,06 \quad$ W5

$\begin{array}{llll}0,05 & 1 & 0,04 & \text { W6 }\end{array}$

$\begin{array}{llll}0,05 & 2 & 0,1 & \text { W7 }\end{array}$

$\begin{array}{llll}0,4 & 3 & 0,12 & \text { W8 }\end{array}$

$\begin{array}{llll}0,03 & 3 & 0,09 & \text { W9 }\end{array}$

Sumber: Hasil analisis, 2017

Tabel 2. External Factor Analysis Summary (IFAS)

No
Faktor Strategi Eksternal

2

$\begin{array}{cccc}\text { Bobot } & \text { Rating } & \text { Skor } & \text { Kode } \\ 3 & 4 & 5 & 6\end{array}$

\section{A Peluang (O)}

1 Promosi potensi wisata di Danau Pulau Satonda melalui

$\begin{array}{llll}0,15 & 3 & 0,45 & \mathrm{O} 1\end{array}$
jejaring internet.

2 Tugas pokok dinas pariwisata yaitu untuk mengelola $\begin{array}{lllll}0,1 & 3 & 0,3 & \text { O2 }\end{array}$ tempat wisata.

3 Meningkatnya tren kunjungan wisatawan dari waktu ke

$\begin{array}{llll}0,15 & 4 & 0,6 & \mathrm{O} 3\end{array}$
waktu baik lokal maupun mancanegara terhadap kegiatan wisata alam sebagai wisata yang berkelanjutan.

4 Lapangan pekerjaan untuk masyarakat di sekitar Danau Pulau Satonda.

5 Wisatawan mempunyai persepsi positif terhadap upaya pengembangan ekowisata di Danau Pulau Satonda.

6 Telah terbentuknya kerjasama antara TWA Danau Pulau Satonda dengan wisata alam lain seperti Pulau Moyo.

$\begin{array}{cccc}0,07 & 3 & 0,21 & \text { O4 } \\ 0,15 & 4 & 0,6 & \text { O5 } \\ 0,09 & 3 & 0,027 & \text { O6 }\end{array}$

\section{B Ancaman (T)}

1 Kerusakan lingkungan akibat penangkapan satwa dan $\begin{array}{llll}0,2 & 1 & 0,2 & \text { T1 }\end{array}$ penangkapan liar hasil laut. 


\begin{tabular}{|c|c|c|c|c|c|}
\hline 2 & $\begin{array}{l}\text { Rendahnya kemampuan sumberdaya manusia lokal yang } \\
\text { menyebabkan masuknya sumberdaya manusia dari luar } \\
\text { daerah. } \\
\text { Jumlah }\end{array}$ & 0,09 & 2 & 0,18 & $\mathrm{~T} 2$ \\
\hline
\end{tabular}

Sumber: Hasil analisis, 2017

Berdasarkan hasil analisis faktor internal

maupun faktor eksternal, pengembangan

Pulau Satonda; menyusun strategi operasional ekowisata TWA Danau diprioritaskan pengembangan dengan berbagai atraksi wisata menggunakan strategi berdasarkan kekuatan dan peluang ( $\mathrm{SO} /$ strength-opportunity). Strategi berdasarkan kekuatan dan peluang tersebut yaitu membangun kesamaan persepsi sebagai tujuan wisata andalan, dengan tetap menonjolkan unsur pendidikan konservasi serta peningkatan ekonomi bagi masyarakat setempat; dan pembangunan forum kegiatan pengelolaan ekowisata.

dan konsep pengembangan ekowisata di Danau

Tabel 2. Alternatif strategi Pengembangan Ekowisata Danau Pulau Satonda

No Strategi Kode Pembobotan Total Prioritas

\section{Strategi SO}

1 Membangun kesamaan persepsi dan konsep pengembangan ekowisata di Danau Pulau Satonda

$\begin{array}{lll}\mathrm{S} 1+\mathrm{S} 2+\mathrm{S} 3+\mathrm{S} 4+\mathrm{S} 5+\mathrm{S} & 04.44 & 1 \\ 6+\mathrm{S} 7+\mathrm{O} 1+\mathrm{O} 2+\mathrm{O} 3+\mathrm{O} & & \\ 4+\mathrm{O} 5+\mathrm{O} 6 & & \\ & & \\ \mathrm{~S} 1+\mathrm{S} 2+\mathrm{S} 3+\mathrm{S} 4+\mathrm{S} 5+\mathrm{S} & 04.44 & 2 \\ 6+\mathrm{S} 7+\mathrm{O} 1+\mathrm{O} 2+\mathrm{O} 3+\mathrm{O} & & \\ 4+\mathrm{O} 5+\mathrm{O} 6 & & \end{array}$

2 Menyusun strategi operasional pengembangan di Danau Pulau Satonda dengan berbagai atraksi wisata sebagai tujuan wisata andalan dengan $4+\mathrm{O} 5+\mathrm{O} 6$ tetap menonjolkan unsur pendidikan konservasi serta peningkatan ekonomi bagi masyarakat setempat

3 Pembentukan forum kegiatan pengelolaan ekowisata

$\begin{array}{lcc}\mathrm{S} 1+\mathrm{S} 2+\mathrm{S} 3+\mathrm{S} 4+\mathrm{S} 5+\mathrm{S} & 04.44 & 3 \\ \text { 6+S7+O1+O2+O3+O } & & \\ \text { 4+O5+O6 } & & \\ \text { W1+W2+W4+W7+W } & 0,128 & 4 \\ \begin{array}{l}\text { 8+W9+O1+O2+O3+ } \\ \text { O5+O6 }\end{array} & 47 & \\ \text { W1+W2+W3+W4+ } & 0,1 & 5 \\ & & \\ \text { W1+W2+W3+W8+O } & 0,101 & 6 \\ 1+\mathrm{O} 2+\mathrm{O} 3+\mathrm{O} 6 & 39 & \end{array}$

4 Peningkatan kualitas produk yang di kemas secara kreatif dan variatif dengan melibatkan masyarakat setempat

5 Peningkatan kerjasama dalam pengembangan dan promosi ekowisata di Danau Pulau Satonda

6 Peningkatan sarana prasarana penunjang wisata yang dibutuhkan

$1+\mathrm{O} 2+\mathrm{O} 3+\mathrm{O} 6$ 1 2

(1)

\section{Strategi ST}


7 Melibatkan masyarakat dalam kegiatan pengelolah kawasan Danau Pulau Satonda dalam proses perencanaan,pelaksanaan dan evaluasi

8 Peningkatan peran masyarakat dalam

pengendalian kerusakan lingkungan

\section{Strategi WT}

9 Pemerataan hasil usaha wisata melalui peningkatan kapasitas SDM masyarakat

Sumber: Hasil analisis, 2017

\section{Kesimpulan}

1. Wisata alam dan budaya yang belum terkemas dengan baik, serta keterbatasan sarana dan prasarana penunjangnya merupakan tantangan utama yang harus diperhatikan dalam pengembangan ekowisata TWA Danau Pulau Satonda.

2. Strategi prioritas yang perlu dilakukan yaitu membangun kesamaan persepsi dan konsep pengembangan ekowisata di Danau Pulau Satonda; menyusun strategi operasional pengembangan dengan berbagai atraksi wisata sebagai tujuan wisata andalan, dengan tetap menonjolkan unsur pendidikan konservasi serta peningkatan ekonomi bagi masyarakat setempat; dan pembangunan forum kegiatan pengelolaan ekowisata.

\section{Saran}

Penelitian ini dapat digunakan sebagai dasar penelitian selanjutnya dalam pengembangan ekowisata TWA Danau Pulau Satonda.

Daftar Pustaka
Fandeli, Chafid dan Muhammad Nurdin. 2005.

Pengembangan EkowisataBerbasis

Konservasi di Taman Nasional.

Fakultas Kehutanan UGM, PusatStudi

Pariwisata UGM, dan Kantor

Kementerian Lingkungan Hidup.

Yogyakarta.

Fandeli, 2005. Pengembangan Ekowisata Berbasis Konservasi di Taman Nasional. UGM. Yogyakarta.

Ismayanti, 2009. Pariwisata Berwawasan Lingkungan. Grafindo Khazanah Ilmu. Jakarta.

MacKinnon, et al. 1990. Pengelolaan Kawasan yang Dilindungi di Daerah Tropika (Terjemahan). Gadjah Mada University Press. Yogyakarta.

Peraturan Pemerintah Nomor 68 tentang Kawasan Suaka Alam dan Kawasan Pelestarian Alam. Departemen Kehutanan. Jakarta.

Riyanto, Budi. 2005. Pemberdayaan $\begin{array}{lr}\text { Masyarakat Sekitar } & \text { Hutan } \\ \text { dalamPerlindungan } & \text { Kawasan }\end{array}$ 
Pelestarian Alam. Lembaga

Pengkajian HukumKehutanan dan

Lingkungan. Bogor.

Soekadijo, R. G. 2000. Anatomi Pariwisata.

Gramedia Pustaka Utama. Jakarta.

Usman. M. 1999. Peluang Pengembangan

Ekoturisme Indonesia sebagai

AndalanAlternatif Kepariwisataan

Nasional, Makalah Pada Seminar

Prospek danManajemen Ekoturisme

Memasuki Milenium Ketiga.

Departemen.

Undang-Undang Nomor 41 Tahun 1999

tentang Konservasi Sumber Daya

Alam dan Ekosistem. Pemerintah

Republik Indonesia.

Undang-Undang Nomor 5 Tahun 1990 tentang

Pariwisata. Pemerintah Republik

Indonesia. 
